\title{
Ely Cathedral and the Afterlife of Ealdorman Byrhtnoth
}

\author{
Katherine Weikert
}

In 1154, seven Anglo-Saxon and Scandinavian men were translated to the new Norman cathedral at Ely (Cambs.) and reburied together in a single monument in the north transept of the cathedral. ${ }^{1}$ One of these men was the Ealdorman Byrhtnoth. Byrhtnoth is of course a well-known figure in late Anglo-Saxon England, with a relatively rich documentary record for the period. He witnessed a number of charters through a long career in the reigns of Æthelred, Edgar, Edward, Eadwig and Eadred, ${ }^{2}$ and was named in the wills of his fatherin-law, Ealdorman Ælfgar, and sister-in-law, Æthelflæd. ${ }^{3}$ He gained a reputation as a virtuous man and spoke in defence of monks who would have been expelled in favour of secular clergy during the 'anti-monastic' reaction following the death of King Edgar in $975 .{ }^{4}$ He predeceased his wife Ælfflæd and so is not mentioned in her will, but there are numerous notices of their joint gifts as well as the gifts of their extended family in Liber Eliensis (II.62-64). His death is recorded in the Anglo-Saxon Chronicle as well as Liber Eliensis, and in more heroic form in the Vita Oswaldi as well as in the well-known poem "The Battle of Maldon."5 This text has been used more than any other in medieval and modern times to reconstruct the persona of this famous and heroic man.

1 I am always grateful to have received guidance, advice and hopefully just a fraction of Barbara Yorke's knowledge as her PhD student 2010-13; I have greatly benefitted from her wisdom and support as both an academic and a human being. My thanks also to Ros Faith, David Green, Charles Insley, Ryan Lavelle, Simon Roffey and Simon Yarrow for very helpful discussion on points of this paper, as well as to the conveners and audiences at seminars and conferences at Oxford, Cardiff, Manchester and Southampton for comments on early stages of research. All remaining errors, of course, are my own.

2 PASE, "Byrhtnoth 1."

$3 \mathrm{~S}_{1483}, \mathrm{~S}_{1494}$

$4 E H D$ 1, no. 236; Richard Abels, "Byrhtnoth [Brihtnoth] (d. 991), Magnate and Soldier," ODNB <https://doi.org/10.1093/ref:odnb/3429> (accessed 12 June 2015); Byrhtferth of Ramsey, Vita S. Oswaldi, IV.13, Byrhtferth of Ramsey: Lives of St Oswald and St Ecgwine, ed. Michael Lapidge (Oxford, 2009), pp. 127-29; LE, II.62, pp. 133-36; trans. Fairweather, pp. 16o-61, n. 295.

5 Asc A, C (D, E), p. 82; Vita Oswaldi V.5, pp. 156-59; "The Battle of Maldon," in The Battle of Maldon AD 991, ed. Donald Scragg (Oxford, 1991), pp. 1-36. 
However, Byrhtnoth was not the only man represented on this monument; he joined six others in this place of honour in Ely. These men represented various identities, local and international, secular and sacred, but grouped together, their identities were transmuted into one that was best for Ely in the 12th century: a worthy and decidedly masculine grouping offered for veneration. These 12th-century representations have been largely understudied, though there is a compelling reason for this: the original monument, spoken of in two 12th-century texts, is lost, as is one of these two texts themselves. However, grouped together, the remaining evidence gives a tantalizing view of what Ely was doing with their past. There is much to read in this monument, but most questions fall under this umbrella: why these men, at this place, at this time? There are three main points to read in this. Firstly, of course, there is the financial impact of new saints. But more importantly, the next two: secondly, the political associations and affiliations that can be read in this particularly interesting selection of men through their group identities. And finally, the spatial implications of its location for a gendered reading of the space.

I take as a starting point here David Lowenthal's writing on the past itself as a foreign country: 6 in presenting these long-dead men as their new and, at the same time, nostalgic worthies, the Anglo-Norman monastery utilized a combination of Anglo-Saxon and Scandinavian men to create a "useable past"7 to best represent their own purposes and identities in the 12th century when, in fact, there would have been significant separations between the personal identities of these pre-Conquest men and the 12th-century monks at Ely. In addition to this, at this time western Europe was in the grips of what Jo Anne McNamara has aptly called the Herrenfrage, a crisis of monastic and sacred masculinities whose solution was for sacred and secular men to "establish their own dominance at any cost." 8 This would include reasserting repetitive versions of hegemonic masculinities available in the 12th century, but in this instance at Ely the martial and saintly aspects of masculinities were brought to the fore in this monument and its placement in the Cathedral. At Ely's refoundation in 970 as a part of the Benedictine reforms, it had become a male-only monastery. ${ }^{9}$ But the monastery was originally founded in the later 7 th century

6 David Lowenthal, The Past is a Foreign Country: Revisited (Cambridge, 2015).

7 Van W. Brooks, "On Creating a Usable Past," The Dial 64:7 (1918), 337-41.

8 Jo Ann McNamara, "The Herrenfrage: The Restructuring of the Gender System 1050-1150," in Medieval Masculinities: Regarding Men in the Middle Ages, ed. Clare A. Lees. (Minneapolis, MN, 1994), pp. 3-29, at p. 19. McNamara's decision to use a German coinage for a "Man Question" is a response to the traditional historiographical notion of a Frauenfrage.

9 "Houses of Benedictine Monks: Abbey and Cathedral Priory of Ely," in VCH Cambs., 2 (1948), pp. 199-210. 
by royal female founders who became saints, Æthelthryth and her companions, sisters, and later abbesses, Wihtburh, Seaxburh, and Eorminhild. ${ }^{10}$ When Ely put their monument to their seven men on an intersecting path to the four women saints, this impacted the creation of a memory culture surrounding their mythologized and nostalgized past. This monument and its contextualized place provides an opportunity to view Ely familiarizing a foreign past to suit their purposes, and at the same time introducing male worthies to their saintly pantheon, metaphorical and spatially interrupting the memory culture of their female founders.

This chapter will approach the memorialization in two separate but intertwined ways. First, I will examine the individual and the group identities of these seven worthy men. By demonstrating Ely's familiarization and use of their own past, we can see the monastery compressing individual identities, particularly those of Ealdorman Byrhtnoth and Bishop Osmund of Skara, into group identities more appropriate for the 12th-century fens, and (particularly in the case of Osmund), making their broadly-travelled lives of secondary importance to their localized importance: the foreign past here did not matter so much as their personae and ability to be used in a political present. Second, the group's identity as specifically male also is key to understanding these men's potential importance of shaping a memory culture at Ely to medieval travellers and pilgrims, intervening in their development of 'memories' about these men and casting their personae in a way that best suited Ely's needs. By considering the lived experience of encountering this memorial on Ely's pilgrim trail we can understand how Ely was actively reconstructing their past through not only written, but also visual means.

\section{The Texts and the Monuments}

In order to fully appreciate what the sources can tell us, we have to discuss a lost text, the physical memorialization at Ely and Liber Eliensis in conjunction with one another, and doubly so as the lost text survives via Liber Eliensis itself. The three are substantially intertwined. The lost manuscript, called the History of Seven Illustrious Men in Janet Fairweather's recent translation of Liber

$10 \quad$ John Crook, "'Vir optimus Wlstanus': The Post-Conquest Commemoration of Archbishop Wulfstan of York at Ely Cathedral," in Wulfstan, Archbishop of York: The Proceedings of the Second Alcuin Conference, ed. Matthew Townend (Turnhout, 2004), pp. 501-24, at p. 524. 
Eliensis, ${ }^{11}$ outlines the lives and deeds of, indeed, seven illustrious men who were crucial patrons to Ely in the late Anglo-Saxon period: Archbishop Wulfstan of York; Bishop Osmund of Skara; Bishops Ælfwine and Ælfgar of Elmham; Eadnoth of Ramsey; Bishop Æthelstan of Elmham; and Byrhtnoth. The History has probably been lost since perhaps as early as the 14th century, based upon a note in the Cambridge manuscript of Liber Eliensis (discussed below). It is assumed to be written by Prior Alexander specifically during the reign of King Stephen, giving it a relatively secure date of $1151 \times 54 .^{12}$ It probably had an intensely localized interest; given the translation of these seven men around the same time, it reads much like a modern guidebook to the tomb of the seven men.

Its inclusion in Liber Eliensis only a couple of decades after its production allowed its survival. The chronicle-cartulary Liber Eliensis tells the history of Ely through the compilation of local history, archived charters, and commentary from a monastic compiler who had knowledge of English, if was not of English ancestry himself. The oldest manuscripts are the E manuscript from the 12th century, Trinity College Cambridge, and the 13th-century F manuscript, Cambridge University Library, a fuller version and one used for both the Blake transcription and the Fairweather translation. ${ }^{13} \mathrm{~A}$ note on the unbound flyleaf of the F manuscript mentions that " $\mathrm{t}$ ] hese are the confessors of Christ, whose bodies lie on the north side of the choir of the church of Ely, separately in loculi (or locelli) in the stone wall," followed by a list of the pious men's names: Wulfstan, Osmund, Ælfwine, Ælfgar, Eadnoth, Æthelstan, Byrhtnoth. ${ }^{14}$ According to Simon Keynes, the hand is a "scrawl" of the second quarter of the

11 Further noted by Blake, in his introduction to his edition of the $L E$, pp. xxxviii; Elizabeth Coatsworth, "Byrhtnoth's Tomb," in The Battle of Maldon AD 991, ed. Scragg, pp. 279-88, at p. 279; and James Bentham, The History and Antiquities of the Conventual and Cathedral Church of Ely from the Foundation of the Monastery, A.D. 673, to the Year 1771 (Norwich, 1812). The lost document will be referred to as the History in the remainder of this article for clarity's sake.

12 Blake, "Introduction," p. xxxviii; “Houses of Benedictine Monks," pp. 199-210.

13 See Fairweather's introduction to her translation of $L E$, pp.xiv-xv; $\mathrm{xxv}-\mathrm{xxvi}$; Trinity College Cambridge MS O.2.1; Cambridge University Library, EDC 1. EDC 1 was consulted for this chapter.

14 "Isti sunt confessores Christi quorum corpora jacent ex parte aquilonari chori ecclesie Eliensis in locellis separatim in pariete lapideo." Cambridge University Library, EDC 1. Translation from Crook, "Vir optimus Wlstanus'," p. 506. Byrhtnoth in this note is titled as the duke of Northumbria, echoing his notation as such in LE II.62. Blake (p. 134, n. 1) suggests that the complier at Ely knew the poem "The Battle of Maldon" and "drew a wrong conclusion" about the language used for a Northumbrian hostage fighting for Byrhtnoth ("on Norðhymbron"). Fairweather (p. 16o, n. 298) notes that only in the Ely tradition is Byrhtnoth associated with Northumbria. By the 13th-century Cambridge University Library: 
14th century, ${ }^{15}$ probably contemporary with the new quire at Ely following the collapse of the Norman tower in 1322 and the men's own retranslation into the quire wall. It is notable that the seven are written as "confessores Christi," and that Byrhtnoth's legacy at this point in the 14th century was not his military or secular identity. ${ }^{16}$ The original History probably talked about the men in order of their placement in the memorial monument in Ely, reading from left to right, and the compiler of Liber Eliensis appears to have more or less done a medieval 'copy-paste' of the details of this text, though rearranging the text to place the men in chronological order rather than their order on the monument. Indeed, the compiler of Liber Eliensis specifically noted that he wrote about these men out of order because of narrative demands (II.87); the narrative was chronological, whilst the positioning of the seven men in situ, from Wulfstan to Byrhtnoth, was not. In fact, chapter 87 of book II of Liber Eliensis - the chapter about Wulfstan-speaks of these men, noting "first of these in order is the excellent man Wulfstan," when by this point in Liber Eliensis, most of the others had already had their chapters. ${ }^{17}$

The occasion of writing the History probably corresponds to the first translation of these men in the 12th century. They were translated a second time into the north quire wall with the build of the new quire in the early 14th century following the collapse of the Norman tower. ${ }^{18}$ They remained there until 18 May 1769 , when these bones again saw the light of day as they were translated a third time from this location to their current site in the chantry chapel of Bishop West. ${ }^{19}$ The seven bodies were placed in the order that they were placed in the 14th-century monument, ${ }^{20}$ likely the same order that they were in during the 1154 translation. Sadly, Liber Eliensis is mainly quiet about the tomb and location of these seven men at their 1154 translation, outside of the mention that the "first in order is Wulfstan" and that the men were placed on the north side of the cathedral (II.87). ${ }^{21}$ The current, 18 th-century monument is thought almost universally to reflect the 14th-century layout of the men.

EDC 1 and the 14th-century note in its flyleaf, the knowledge and memory of his office had already been transmuted.

15 Cited in Crook, "Vir optimus Wlstanus," p. 506.

16 Coatsworth, “Byrhtnoth's Tomb," p. 280.

$17 L E$, trans. Fairweather, p. 185.

18 C.W. Stubbs, Historical Memorials of Ely Cathedral (Ely, 1897), p. 91.

19 R.J. King, "Ely Cathedral," in his Handbook to the Cathedrals of England (London, 1862). Available at <http://penelope.uchicago.edu/Thayer/E/Gazetteer/Places/Europe/Great_ Britain/England/_Topics/churches/_Texts/KINCAT*/Ely/1.html> (accessed 13 Mar. 2015).

20 Stubbs, Historical, pp. 92-93.

$21 L E$, trans. Fairweather, p. 185. 
Based upon remaining stonework, drawings of the 14th-century monument, and antiquarian records from the 18th century, T.D. Atkinson and John Crook also claim that this alignment could reflect the 12th-century line-up. ${ }^{22}$ Fairweather has also noted that the order of these seven worthies, in a monument facing north with names reading Wulfstan to Byrhtnoth from left to right, followed precedence: the archbishop and possible saint, arguably the most holy, was (and indeed still is) to the east with the sole secular patron, Byrhtnoth, to the west. ${ }^{23}$

It must be acknowledged that there is no material evidence to definitively place this memorial to the seven worthies within the cathedral to which they were transferred in the mid 12th century. The 12th-century memorial, as mentioned, has not survived to the present day. But this memorial has long been researched, considered, and recorded from the 12th century till today, in terms of its size, its style, and its form. Antiquarian drawings of the 14th-century shrine record in general terms the 14th-century monument that was mostly destroyed in the 18th-century translation; most recently, John Crook has examined these drawings alongside the cathedral fabric itself for indications of accuracy and structure. ${ }^{24}$ Research from Crook and Atkinson place the 12th-century monument in the north side of the crossing, between the Norman piers, facing into the north transept. ${ }^{25}$ This is also a convenient placement as it would be where the men would stay until their movement in the 18th century to facilitate the quire being moved north, out of the octagon. But what we can build from this contextualization of evidence and simple placement of the monument is a further ability to examine the monument and its place in much more detail, not only in its interpretation via group identities, but through its spatial arrangement within the Cathedral itself.

The group identities are painted for us most clearly through the History/ Liber Eliensis. The History/Liber portrays a slightly altered Byrhtnoth from the man of the poem, mostly in the focus of his generosity to the abbey, but he still displays the appropriate ranges of heroic masculinity. For example, Byrhtnoth

22 "City of Ely: Cathedral," in $v c H$ Cambs. 4 (2002), pp. 50-77; Crook, "Vir optimus Wlstanus'," p.521.

23 Janet Fairweather, Bishop Osmund: A Missionary to Sweden in the Late Viking Age (Skara, 2014), p. 330.

24 Crook, "Vir optimus Wlstanus"'

25 Crook, "Vir optimus Wlstanus,", p. 516; John Crook, English Medieval Shrines (Woodbridge, 2011), pp. 178-79; T.D. Atkinson, et al., "City of Ely: Cathedral," in vcH Cambs. 4:50-77; Eric Fernie, "Observations on the Norman Plan of Ely Cathedral," in Medieval Art and Architecture at Ely Cathedral, British Archaeological Association Conference Transactions 2 (London, 1979), pp. 1-7. 
is still brave and daring. He was "indefatigable in soldiering and warfare, courageous beyond all measure"; he was incited to "daring" by messages from the vikings to, essentially, come and get them. He fought forcefully for fourteen days and was still fighting when his head was cut off ( $L E$ II.62), much in the same way the Byrhtnoth of poem was still kicking it when his arm was taken off,, ${ }^{26}$ and indeed the Byrhtnoth of Vita S. Oswaldi takes the biblical allusions of fighting to the left and the right while going down in a blaze of glory. ${ }^{27}$ But the Byrhtnoth of Liber Eliensis is also quite a comrade; he refuses to stay at Ramsey when they refuse to fete all of his men: "I will not dine alone without the men you refer to, because I cannot fight alone without them" (II.62). ${ }^{28}$ Underlining the importance of this camaraderie, a post-13th-century reader of Liber Eliensis even took care to highlight this passage in the marginalia of the Cambridge University Library EDC 1 manuscript.

Perhaps as would be appropriate to a monastic cartulary, the Byrhtnoth of the History/Liber also takes on more typically venerable features. Byrhtnoth "honoured Holy Church and the servants of God everywhere" (LE II.62), ${ }^{29}$ probably in reference to his vehement defence of monks against secular clergy noted in the Liber Eliensis (II.51) and Vita Oswaldi in $975 .{ }^{30}$ But this Byrhtnoth goes beyond these words from decades before and puts this defence of holiness into action at Ely. Before battle, in gratefulness for the monks' hospitality, Byrhtnoth gives Ely a laundry list of estates and precious moveable goods. The Liber Eliensis Byrhtnoth dies in battle and is retrieved by the monks at Ely; they replace his head with one of wax and bury him at Ely (II.62). Beyond Byrhtnoth's actions, more is made of his generosity via his family; both his wife and her sister are mentioned in the next two chapters of Liber Eliensis, giving estates and objects like a wall-hanging illustrating the deeds of the heroically deceased Byrhtnoth (II.63, 64). So this Byrhtnoth is no less courageous and has all of his military masculinity trappings, but Liber Eliensis also casts his as considerably more generous and not only as a defender of the realm but a defender of Ely and the church.

But Byrhtnoth was only one of seven in this text and this monument. The eagerness to read Byrhtnoth from these texts has overshadowed the importance of establishing a group identity or identities to these seven who were

\footnotetext{
26 "Battle of Maldon," ed. Scragg, lines 160-84.

27 Vita Oswaldi v.5, p. 157.

28 "Sciat dominus abbas, quod solus sine istis nolo prandere, quia solus sine illis nequeo pugnare;" $L E$, trans. Fairweather, p. 162.

29 "Preterea sanctum ecclesiam et Dei ministros ubique honorabat;" $L E$, trans. Fairweather, p. 160.

$30 \quad$ Vita Oswaldi IV.13, pp.127-29.
} 
remembered together, and how the memories of these men were developed and underlined by both the History/Liber and the monument. Elizabeth Coatsworth has already noted that these seven were translated from the AngloSaxon cathedral as a group, not as individuals, and Byrhtnoth was not made distinct from the other six as a "lay hero,"31 and this needs further examination. Group identities, and how they are represented, are here key to understanding the purpose of this monument in shaping the memory of the past in the 12thcentury cathedral. Each individual, examined here in order of their appearance in the monument, needs to be considered in order to discern these group identities.

Wulfstan (d. 1023) was "one of the half dozen most significant figures even in the crowded and dramatic history of 11th-century England"; as a writer of both homilies and legislation his stamp was felt strongly in the English and European culture of the time. ${ }^{32}$ Although no vita was written about him, the History/Liber chooses to record details of a typically hagiographic nature about his determination to be buried at Ely thanks to his crosier sinking half-way into the floor at Ely during a procession. There are further details of miracles at his tomb, including the healing of diseases. Moreover, Liber Eliensis (II.87) helpfully notes that, although Wulfstan's body had decayed, there were convenient contact relics such as his chasuble, stole, maniple, and gilded pins available, and even casts as miraculous that these objects were still around despite the time lapse from their burial and their proximity to a decaying body! Joyce Tally Lionarons has already noted that Ely was trying to capitalize on the status of Wulfstan to propagate a cult by the report of the miracles at his grave; ${ }^{33}$ here, the History/Liber is practically waving a flag to point out that there is still plenty to see here, despite the lack of a saintly body.

The biographical details of Bishop Osmund (d. no later than 1075) have been somewhat contested, although recent work has shed more light on his life and times. ${ }^{34}$ Albeit not much described in the History/Liber, Osmund appears to have been a well-travelled and well-learned (if controversial) figure. He was trained in Bremen, travelled to Rome where he was "repulsed" and left without episcopal orders but subsequently consecrated in the Polish archbishopric of

31 Coatsworth, "Byrhtnoth's Tomb," p. 280.

32 Patrick Wormald, "Wulfstan (d. 1023)," ODNB <https://doi.org/10.1093/ref:odnb/30098> (accessed 12 June 2015).

33 Joyce Tally Lionarons, The Homiletic Writings of Archbishop Wulfstan: A Critical Study (Woodbridge, 2010), p. 10.

34 Fairweather, Bishop Osmund. The date of Osmund's death is discussed at p. 330. 
Gniezno, or the territory of Kieven Rus'. ${ }^{35}$ Osmund then went to Sweden where he was the bishop of Skara and had archiepiscopal aspirations. ${ }^{36}$ He was adept at Byzantine doctrine, and was possibly brought to Sweden to help create a "'national' Church."37 Adam of Bremen found Osmund a questionable figure; however, Skara was a "neglected" see of Bremen, and Bremen's renewed attention on Skara led to the insertion of a new bishop in the place of Osmund. ${ }^{38}$ The struggle for control of Skara between Bremen and the Swedish kings explains much of Adam's ire. Whatever Osmund's reputation within the spheres of Skara and Bremen, though, it apparently did not proceed him to Ely, or at least was not important to the 12th-century writers. The History/Liber instead primarily speaks of his attachment to King Edward and subsequently to Ely in his retirement ( $L E$ II.99). This international figure of sacred rank and secular consultation was placed next to Wulfstan on the monument, the archbishop, perhaps indicating Osmund's ranking as important in a number of contexts, not just to Ely.

Bishop Ælfwine of Elmham (d. by $1038^{39}$ ) was a well-known entity to Ely, having been at Ely as a child oblate before being raised to the bishopric of Elmham in the time of King Æthelred ( $L E$ II.75). His depiction on the monument and the History/Liber retains the importance of the locality of Ely although probably partly through necessity: by the time of writing the History, the bishopric of Elmham was no longer extant, having been transferred to Thetford and subsequently to Norwich. The History/Liber portrays Ælfwine as holy and but mostly as generous, including naming estates given to Ely by the bishop and his parents; the texts also note with some importance that Ælfwine brought monks to Bury St Edmunds (II.75).

Bishop Ælfgar of Elmham (d. $\left.1020^{40}\right)$ preceded Ælfwine in the post, but appeared to Ælfwine's right on the monument. Ælfgar gets double mention in the History/Liber, first as the person to bury Bishop Eadnoth in secret because of Ælfgar's insistence that Eadnoth was a martyr ( $L E$ II.71) (discussed below), and second in his own right as one of Ely's worthies (II.72). The History/Liber particularly wants to paint Ælfgar in tones suitable for one with close proximity to

35 Per Beskow, "Byzantine Influence in the Conversion of the Baltic Region?" The Cross Goes North: Processes of Conversion in Northern Europe, A.D 300-1300, ed. Martin Carver (Woodbridge, 2005), pp. 559-63, at p. 562; P.H. Sawyer, Kings and Vikings: Scandinavia in Europe A.D. 700-1100 (London, 1982), p. 141.

36 Fairweather, Bishop Osmund, p. 283; 294-96.

37 Sawyer, Kings and Vikings, p. 141.

38 Fairweather, Bishop Osmund, p. 298.

39 PASE, "Ælfwine 47."

40 PASE, "Ælfgar 31." 
martyrs and saints, carefully noting Ælfgar's association with Dunstan, Archbishop of Canterbury, already canonized by the mid-12th century and a popular figure. According to the History/Liber, which freely acknowledges the information from Osbert's Life of Dunstan, Ælfgar received a vision of Dunstan being requested by angels to join them, predicting both the man's death, acceptance into heaven, and sainthood. Ælfgar also, of course, retires to Ely.

Bishop Eadnoth of Dorchester, Abbot of Ramsey (d. 1016 $6^{41}$ ) has an especially packed notice in the History/Liber, and another one packed with contact with saints ( $L E$ II.71). As Abbot of Ramsey, he received news of the vision of a craftsman about the body of Saint Ives of Ramsey, which Eadnoth promptly had brought to Ramsey. Following this, as bishop of Dorchester, he also translated to London the body of St Ælfheah, martyred by vikings in Canterbury in 1012. ${ }^{42}$ Finally, Eadnoth himself is killed by Cnut's men at Assandun: his hand first cut off for a ring, and then his body hacked to pieces, as he and Abbot Wulfsige chant mass on behalf of Edmund Ironside's men. They made a good end. Ælfgar, referenced above, stole Eadnoth's body from its drunk guardians and buried it at Ely. This was done for several reasons: firstly to increase the reputation of Ely, secondly because Ælfgar knew of Eadnoth's love of the female saints of Ely, and finally because Ælfgar believed Eadnoth to be a martyr. Having received such a vision of Dunstan's death and sainthood, who would doubt Ælfgar's word?

The final worthy save Byrhtnoth was Æthelstan, another bishop of Elmham (d. after ${ }^{1001^{43}}$ ). His depiction in the History/Liber is dry in comparison to the others: he is depicted as a holy man, who gave Ely much by way of property both in land and moveable goods, and who opted to be buried at Ely ( $L E$ II.65). Ælfgar, his predecessor at Elmham, is noted as following his example (II.72).

To read this monument, let's return to the questions I posed at the beginning and the three main ways that this translation and monument can be read. First, the most cynical (or perhaps simply the most practical) interpretation focuses on the financial impact of cultivating new saints at a place already well-known for its existing Anglo-Saxon saints, and in thus doing draw more pilgrims to Ely. Saints' presence increased the prestige of the institution, but the heavy footfall of pilgrims would also increase the income. Saint Æthelthryth and her companions, Wihtburh, Seaxburh, and Eorminhild were translated to the Ely's Norman cathedral in 1106 and placed behind the high altar, and by the late 12th century, Ely was taking full advantage of their female

\footnotetext{
41 PASE, "Eadnoth 11."

$42 \operatorname{Asc} \mathrm{C}(\mathrm{D}, \mathrm{E})$, p. 91.

43 PASE, “Æthelstan 56 ."
} 
Anglo-Saxon saints. ${ }^{44}$ Indeed, by the 14 th century when the pilgrimage Æthelthryth's shrine is at its peak, ${ }^{45}$ cathedral rolls indicate that this shrine was taking in nearly double the moneys taken in at the High Altar, to the tune of some $£_{40}$ per annum. ${ }^{46}$ The income from these saints, in fact, appears to rise steadily from the available records when it first appears in the sacrists' rolls in 1302/3 with an income of $£ 11$, to its high point in the available records at $£ 94$ 9s. 1od. in 1408/9. ${ }^{47}$ By the $13^{\text {th }}$ century, with Bishop Northwold's extension of the presbytery, the shrine was heavily trafficked and had its own entrance in the north transept. Northwold's works were not only to "make room for the Magnificent Shrine of S. Etheldreda" in James Bentham's view ${ }^{48}$ but to really make room for the numerous pilgrims coming to Ely to see this saint. In addition to this, in the reign of Henry I (prior to the translation of the male worthies but after the translation of the female saints), Ely was granted the right to hold a fair on the feast of St Æthelthryth and three days before and after, ${ }^{49}$ increasing the income that could be had through the celebration of the saint. Saints were good business to a cathedral.

Second, the group identities of these collected men make a great impact on their interpretation. The first and most obvious link between the men is that they were all, of course, men. More on this below. But a second link is that they all had an intensely localized interest in or association to Ely in their lives or afterlives. Ely was essentially the retirement home of Osmund, Ælfgar and Æthelstan and the location of the child-oblate stage of the career of Ælfwine. Eadnoth and Wulfstan's associations are further pitched in specifically spiritual tones: Eadnoth because of his intense love of the female Anglo-Saxon saints there (perhaps a flimsy but acceptable excuse for Ælfgar's body-snatching), and Wulfstan through the miracle of his crosier choosing his place of burial there, as well as the miracles reported at his grave. But in this localized group identity, Osmund's episcopal career as intensely Continental, almost entirely taking place in central Europe and Scandinavia, was flattened in favour of his retirement to Ely. None of this life or these deeds are important to Ely. In

44 Crook, "'Vir optimus Wlstanus," p. 524.

45 Virginia Blanton, Signs of Devotion: The Cult of St. Ethelthryth in Medieval England, 6951615 (University Park, PA, 2010), p. 9.

46 Martin Locker, "The Medieval Pilgrimage from Ely to Walsingham: A Landscape Sensory Perspective." Unpublished conference paper, University of London Institute of Archaeology Graduate Conference, February 2011. Available at <https://www.academia. edu/2043915> (accessed 5 Apr. 2018).

47 Ben Nilson, Cathedral Shrines of Medieval England (Woodbridge, 1998), pp. 154-55.

48 Bentham, History and Antiquities, p. 254.

49 Charter printed in Bentham, History and Antiquities, Appendix, p. 18, no. 13. 
fact, the only indications of his non-English career is in that the Liber/History mentions that he arrived in England from "the region of Sweden where he had been bishop" (LE II.99). ${ }^{50}$ His actual origin is now debated as either AngloSaxon or Norwegian, but to all intents and purposes the Liber/History Anglicizes him for the sake of maintaining an intensely localized importance to these seven worthies; his foreignness (and note-worthy career) are glossed over for the sake of making him familiar, local, English.

Another group identity that is clear in the History/Liber is that of patronage, displayed through not only the monument but the monastic archive at the time. Byrhtnoth, Wulfstan, Æthelstan, Ælfwine and his family, and Osmund are all noted as patrons of Ely, having given gifts of properties and goods. Æthelstan is noted for his generosity more so than his saintliness, described as a "donor of outstanding liberality" in a passage that further notes the presence of Æthelstan having witnessed charters of the abbey ( $L E$ II.65). ${ }^{51}$ The passage describing Wulfstan's patronage also details his confirmation of charters in favour of Ely, while the sections on Ælfwine's patronage are likely at least partial copies of charters ( $L E$ II.87, 75, 86). Portions describing the gifts of Byrhtnoth and his family too are likely taken from monastic archives, including copies of, or at least knowledge of the content of, the wills of Leofflæd, his daughter, and Thurstan, his great-grandson (II.62-64, 67, 88-89). ${ }^{52}$ The repetition of these charters is particularly interesting here as the will of Thurstan disposes three estates inherited from his family in settlement outside of Ely, their intended remainderman: ${ }^{33}$ Wimbish and Pentlow in Essex, and Kedington in Suffolk, are all noted by Liber Eliensis as a gift to Ely from Thurstan's parents, but Thurstan's will disposes of them otherwise. The charters weren't enough to retain the properties; the F manuscript of the Liber, compiled in the mid-13th century, made a point of reiterating these gifts, though long-lost. ${ }^{54}$ But despite slips through the cracks such as this, the monument served to remind as a visual prompt to the visitors to the abbey of both these men's gifts, and the benefits of generosity to the abbey. In a way, the monument served as a more

50 "[D]e Sueðtheda [sic.] regione, ubi episcopus extiterat;" $L E$, trans. Fairweather, p. 201.

$5^{1} \quad$ "precipua largitate erga ecclesiam istam munificus"; $L E$, trans. Fairweather, p. 164.

$5^{2}$ S 1520 (archived at Ely); S 1530 (archived at Canterbury); S 1531 (archived at Bury St Edmunds).

53 Katherine Weikert, Authority, Space and Gender in the Anglo-Norman World (Woodbridge, 2020).

54 Blake notes that "later agreement [may have been] made with the testators' kin, for no complaint of usurpation is made": "Foreword," in Liber Eliensis (London, 1962), p. xi; whilst there is no complaint in $L E$ about these estates, there is no point mentioning them if Ely did not at least still have their eyes on past wrongs. 
general, but more visible, reiteration and confirmation of the charters that the compiler of the Liber was writing about. ${ }^{55}$ The memory of the gifts, and the confirmation of the gifts, were served up in visual form to a larger audience of the pilgrims at Ely, a reminder of the virtues of generosity particularly when given to Ely.

Another group identity is that of their holiness, with many of the men portrayed as potential saints or having strong ties with exiting holy men, almost as contact relics themselves. Ælfgar has visions associated with his former colleague, Saint Dunstan, as well as being in close contact with the body of the martyred Eadnoth. Eadnoth, prior to his own martyrdom, was in close contact with the saintly bodies of Ives and Ælfheah. Wulfstan is, of course, being presented as a saint in the making. Byrhtnoth, it has already been noted, is not here an exemplar of a secular hero ${ }^{56}$ but instead cast in the light of these holy men. Translation, too, plays a strong part in this group identity as holy men, with Ælfgar playing a part with Eadnoth's translation, and Eadnoth himself involved with the translations of Ives and Ælfheah. The translation of these seven worthies from the old Anglo-Saxon church is also a key part of casting these men as new saints, even if the distance travelled was not great. The systematic papal control of canonization was not confirmed until 1298. Rita Tekippe has noted that "[translation] to a devotional site was part of the essential recognition of that person as a saint, and often constituted the second phase of the elevatio, up to the 12th and 13th centuries." ${ }^{57}$ Tekippe also points out that the translation from a grave site to a cult centre was a "point of solemn, ceremonial acknowledgement of the relics as signifier of the saint ... crucial in the establishment of the cult." ${ }^{58}$ This can certainly be seen with the ceremony recorded of the translation of the female saints in 1106 and indeed again at their movement into the new presbytery in the mid 13th century, with the king present and Bishop Northwold granting indulgences to all present at the ceremony. ${ }^{59}$ In translating these men together, Ely was marking their group identity in terms of their holiness but also certainly laying the groundwork for their potential sainthood. Their group translation in 1154 was a hope for the repeated

55 Simon Yarrow, pers. comm.

56 Coatsworth, “Byrhtnoth's Tomb," p. 280.

57 Rita Tekippe, "Pilgrimage and Procession: Correlations of Meaning, Practice, and Effects," in Art and Architecture of Late Medieval Pilgrimage in Northern Europe and the British Isles, ed. Sarah Blick and Rita Tekippe (Leiden 2005), pp. 693-751, at p. 707.

58 Tekippe, "Pilgrimage and Procession," p. 708.

59 Virginia Blanton, "Building a Presbytery for St. Æthelthryth: Bishop Hugh de Northwold and the Politics of Cult Production in Thirteenth-Century England," in Art and Architecture of Late Medieval Pilgrimage, ed. Blick and Tekippe, pp. 539-65, at p. 541. 
success of the female translations in 1106, and no doubt a part of the attempt to create new saints for Ely.

But an identity that is found in subtext here is an intensely strong connection between these men of resistance, and resistance in particular to viking threats and raids. This is where Byrhtnoth's identity, alongside his role as patron to Ely, is most closely tied to these other holy men, and where the group identity most closely relates to him. Both Byrhtnoth and Eadnoth died directly in battle with vikings, Byrhtnoth wielding a sword and Eadnoth wielding prayers. Eadnoth is further associated with the martyred Saint Ælfheah, killed by vikings as a hostage in 1012. Eadnoth is specifically called a martyr through the mouth of Ælfgar; Byrhtnoth, through his secular heroic identity, could be cast in the same light. The Maldon poem has Byrhtnoth dying with a prayer on his lips, whilst the Vita Oswaldi casts his fighting and death in biblical tones. ${ }^{60}$ Poetic and hagiographic tropes no doubt, but ones helpful in establishing the creation of a holy man after the fact. Wulfstan's well-known Sermo Lupi ad Anglos from 1014 also works in a resistance identity, both in its secular and sacred chastisements of the English peoples, making an uncomfortable attempt at stirring resistance whilst offering consolation. ${ }^{61}$ If his foreign identity could be usable to Ely in any context, Osmund too might be cast in this role too: in attempting to assist the king of Sweden in establishing a 'national' church, ${ }^{62}$ he could perhaps be seen as working against pagan raiders and killers, subverting their cultural norms that would result in the deaths of men like Byrhtnoth and Eadnoth.

So why then, at this place, at this time, commemorate a group of men whose group identity was fiercely localized, strongly generous, certainly saintly, and finally symbolic of political resistance? Ely, it is worth remembering, was well known as a place for resistance and rebellion by the late 12th century. Resistance to vikings would be the earliest action, seen here in Byrhtnoth, Eadnoth and Wulfstan (and perhaps in some degree in Osmund). Beyond the time of the vikings, Liber Eliensis was well aware of Hereward's resistance to the Normans, and in fact helped to perpetuate the myth or history through its dissemination in the Gesta Herewardi and beyond. Virginia Blanton has written as well about Ely viewing themselves as "victims of aggression during the Norman invasion” and has read the Æthelthryth shrine as a symbol of the monastery's

$60 \quad$ "Maldon," ed. Scragg, lines 171-180; Vita Oswaldi, v.5, p. 157, n. 55.

61 Andreas Lemke, "Fear-Mongering, Political Shrewdness or Setting the Stage for a 'Holy Society'?-Wulfstan's Sermo Lupi ad Anglos," English Studies 95:7 (2014), 758-776.

62 Sawyer, Kings and Vikings, p. 141. 
"desire for independence, sovereignty and impenetrability."63 The mid-12th century saw Ely again as a centre of resistance and rebellion in the mass entanglement of Nigel, bishop of Ely, with the power structures of the civil war period. Nigel played both sides with some success, moving between Stephen and Matilda's faction as needed. ${ }^{64}$ Indeed Liber Eliensis itself has been read as an expression of "monastic anxieties in the midst of a major political and cultural shift" in the 12th century, and that the monastery envisioned itself as "victims of royal rapaciousness." ${ }^{65}$ By the time of the translation of these AngloSaxon worthies and the writing of the History, Nigel appeared to have made peace with both factions, witnessing the charter assuring the kingdom to the future Henry II in 1153 as well as attending his coronation in late 1154 .

Blanton has already noted that the descriptions of viking and Norman invaders in Liber Eliensis "poses an indirect but clear warning to those who threaten the monastic space at Ely" and that the text itself is positioned as a "personal representation of a community that envisioned itself as a threatened space".66 This text reached a learned audience of probably monastic and royal readers. The monument served a similar purpose, but to a different audience and through different means. In creating a monument that included resistance as a group identity, Prior Alexander and the monks at Ely were quietly acknowledging not only recent history but their existence for two centuries at the centre of rebellions and resistance to vikings via their role with Byrhtnoth and Maldon, Normans with their infamous Hereward the Wake, and the empress and the king via Bishop Nigel's machinations, depending on what year it happened to be. But this audience would be to the audience of those visiting the shrine: locals, travellers, secular and sacred alike. By the time of the mid13th century and certainly by the 14th century, lay pilgrimage at Ely was the norm rather than royal patronage; 67 this later audience surely indicates the early audience and a slow, steady build of non-royal lay pilgrims to Ely. Depending on the route taken, Ely was on the way from London to Walsingham,

63 Virginia Blanton-Whetsell, "Tota integra, tota incorrupta: The Shrine of St. Æthelthryth as Symbol of Monastic Autonomy," Journal of Medieval and Early Modern Studies 32:2 (2002), 227-267, at pp. 232-33. She also provides a thorough overview and analysis of Liber Eliensis and resistance to Normans, particularly in regards to the imagery of the incorruptibility of Æthelthryth, at pp. $248-56$.

64 For a reconstruction, see John Hudson, “Nigel (c.1100-1169)," ODNB <https://doi.org/10.1093 /ref:odnb/2019o> (accessed 12 June 2015).

65 Blanton-Whetsell, "Tota integra," p. 234.

66 Blanton-Whetsell, "Tota integra," pp. 235, 244-45.

67 Blanton, "Building a Presbytery," p. 543. 
"England's Nazareth." ${ }^{68}$ The audience for this monument was a significant one from across England and further afield.

But Nigel's relationship with the monks at Ely had always been uneasy, and this in a timeframe when the conventual church was already at the end stages of a possibly uncomfortable transition to a bishopric and cathedral from 1109, leading to separate identities forged out of what used to be a singular entity. For decades, Nigel, only the second bishop at Ely, had treated monastic and bishopric properties as his own in terms of use and disposal. In the early years of Henry II this was still at play through a series of monastic records from 1156 recorded in Liber Eliensis dictating the return of the state of Ely as when Nigel took office (LE III. 123-29). As Fairweather has mentioned, "the monks of Ely were not noted for deference to their bishops' opinions." ${ }^{\prime 9}$ In addition to simply noting a state of resistance, a feeling of being under constant threat during the civil war period when the Isle saw itself sieged and defended, with this monument the monks were noting their resistance to Nigel.

It would be a position with a certain amount of plausible deniability, if the monks and Prior Alexander were pressed. The overt message to the monument would certainly be saintliness, secular patrons, and the prestige of the institution. The subtext of this monument, however, was resistance to invasion or incursion, exemplified by Byrhtnoth and Eadnoth, and perhaps Osmund here would represent the monks' attempts to work with the system of oppression rather than against it. But in utilizing a group identity that includes resistance to vikings, this monument represents not only the monastery and cathedral as a traditional place of resistance, but also the fermenting trouble at Ely against their bishop. On a certain level, the venerable men who resisted vikings who not only killed but stole property gave the monks at Ely something to identify with in their struggle to reinstate the properties that Nigel had taken from Ely.

\section{The Spatial Arrangements of the Monument}

Finally, the group identity of these worthies as venerable men also needs to be considered. Here the spatial placement of this monument gives a very particular social impact on those viewing it. As Simon Roffey has pointed out in his work on chantry chapels, the spatial and visual relationships between features have an important impact of how to 'read' monuments within churches. ${ }^{70}$

68 Locker, "Medieval Pilgrimage from Ely to Walsingham."

69 Fairweather, "Introduction," p. xxii.

$70 \quad$ Simon Roffey, The Medieval Chantry Chapel: An Archaeology (Woodbridge, 2007), p. 41. 
Pierre Bourdieu has stated that "the meaning objectified in things or places is fully revealed only in the practices structured according to the same schemes which are organized in relation to them." ${ }^{.11}$ The Byrhtnoth monument at Ely can only be understood in relation to the place and the practices that sought meaning in it. As already noted, by the time of the translation and new monument to these Anglo-Saxon men, Ely was a busy place for pilgrims seeking the shrines of Æthelthryth, Wihtburh, Seaxburh, and Eorminhild. ${ }^{72}$ This shrine was located in the far east of the cathedral. The use of the space of the cathedral by pilgrims is important in thinking about approaching both the female saints' shrine and the new Byrhtnoth tomb and memorial. Access to the shrine lay upon a pathway through which one would arguably encounter Byrhtnoth first, before any other of the seven worthies and certainly even the female saints themselves.

Understanding the approach to both the monument and the shrine is crucial to understanding the spatial meaning of the monument within the Cathedral. There were possibly three entrances to the cathedral that pilgrims would use to access the monument and the shrine in the late 12th century: through the nave, or through one of two doors in the north transept. First, and most likely for access, is the door in the west end of the north transept. The current iteration in the cathedral fabric is the result of an early 18th-century rebuild after a wall collapse so the fabric gives us no indication to its earlier roots, though by the Reformation this was the access point referred to by Atkinson as the "pilgrim's entry."73 In this instance, the pilgrim would enter the cathedral precinct through Stepil Gate from Stepil Row, modern High Street, or perhaps via the market at the St Æthelthryth Gate, the site of which is newly discovered to the immediate east of the Almonry, ${ }^{74}$ and proceed to this door. Once inside the pilgrim would be in an aisle on the west end of the north transept, with the massive late Norman composite piers to their left and a running bench along the wall to the right. ${ }^{75}$ The pilgrim would proceed through the aisle before reaching the crossing-the exact location of Byrhtnoth-and carrying on to the left to reach the shrine to the east, passing the Byrhtnoth monument on the north side of the crossing (See Figs. 26.1 and 26.2).

\footnotetext{
71 Pierre Bourdieu, Outline of a Theory of Practice (Cambridge, 1977), p. 90.

72 Crook, "'Vir optimus Wlstanus,", p. 524.

73 Atkinson et al., "City of Ely: Cathedral."

74 Peter Boyer and Tom Woolhouse, "Archaeological Excavation on the Site of the Almonry Restaurant Extension, Ely Cathedral, Cambridgeshire." Unpublished excavation report, Pre-Construct Archaeology, May $2013<$ https://doi.org/10.5284/1027716>. 


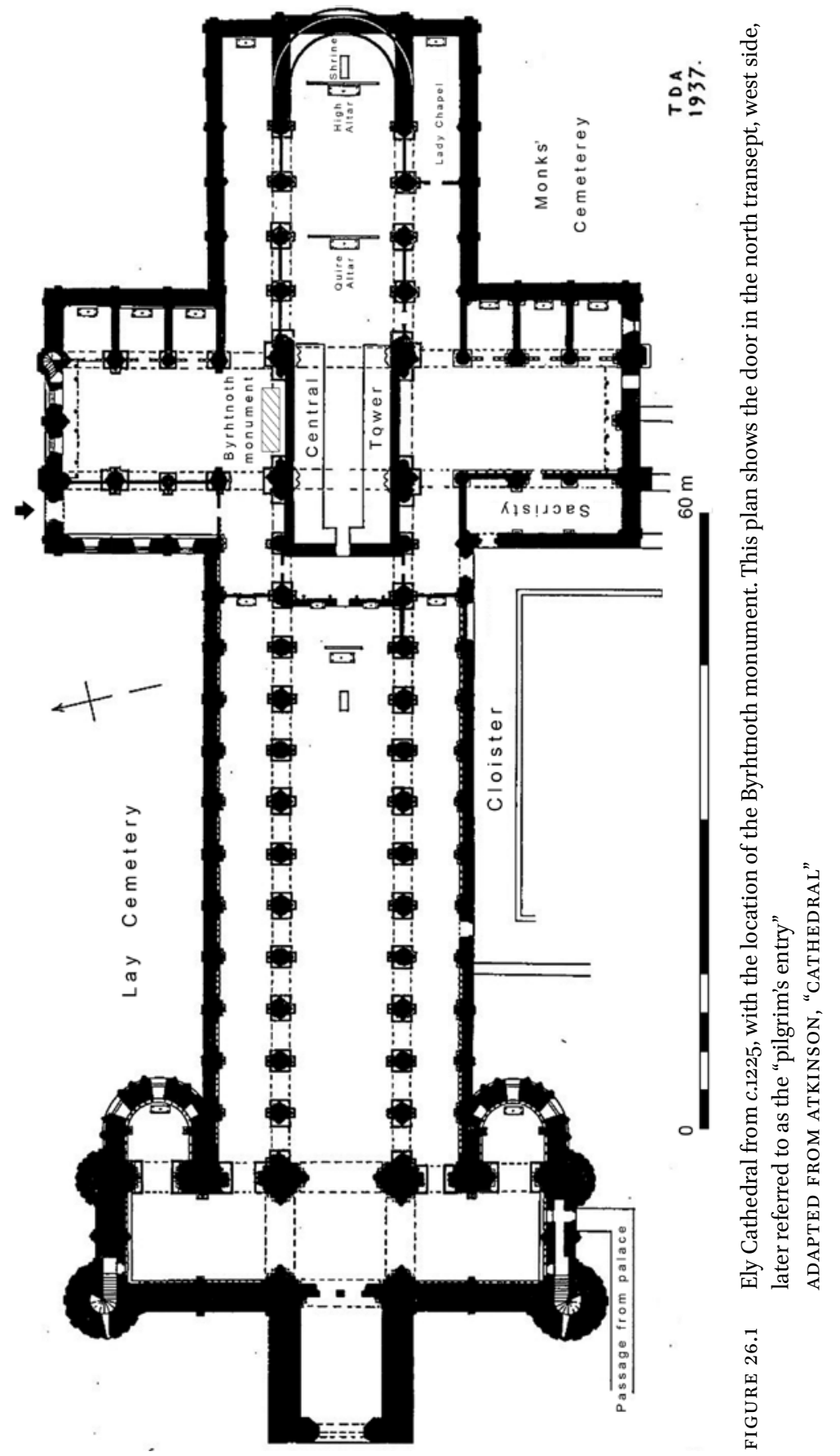



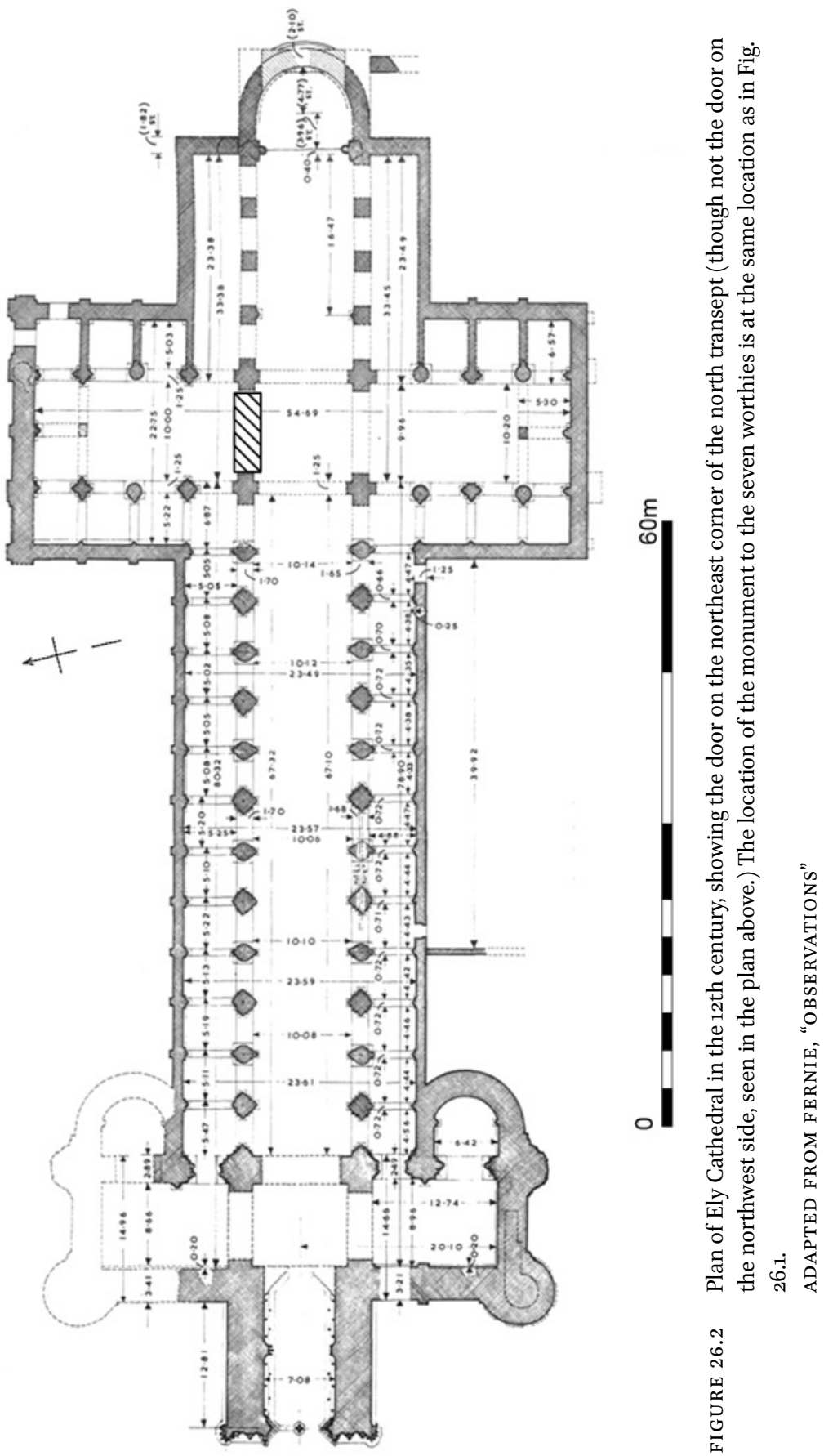
The second door, on the east end of the north transept, looks like a late 12thcentury door; its decorated stonework matches the scheme on the exterior wall, but the door very clearly interrupts the original window. It is certainly a later insertion from the original build, though as to when is unclear. From the early 14th century it served as an exterior entry point to the Lady Chapel. ${ }^{76}$ The door here is from after the initial Norman construction but possibly for more specific access to the chapels on the eastern end of the transept. The eastern aisles of the transept were walled off for chapels, and remained that way at the time of the 12th-century translation, indicating that this place inside the door was probably still a chapel in the years before the build of the Lady Chapel. This entry on the eastern side of the north transept seems more likely to be one specified for this chapel entry. It was certainly possible that pilgrims used it to access the cathedral, but its primary purpose was not for this reason.

Entering through the nave is also likely; as Nilson mentions, it was the "public part of the church and the only area where lay people could gather[...] Admission to the nave was easy, since it was open during regular daylight hours."77 This access would necessitate the pilgrim to move from the nave to the north aisle at least by the time they reached the eleventh pier where a pulpitum blocked access further east to the quire, ${ }^{78}$ though more likely before with the location of the altar at the tenth pier. Movement to the north aisle instead of the south is considered implied if not axiomatic, as moving to the south aisle would interfere with the monastic processions to service, with the prior's door and monk's door both located in the south nave aisle. Additionally, Pam Graves has demonstrated that the iconography of the northern sides of English churches tends to be associated with evil, darkness and the Crucifixion, and the south with good, light and the Resurrection $;{ }^{79}$ perhaps here too this north/ south divide is indicative of secular and sacred traffic. Having moved into the north aisle, the pilgrim would progress into the north transept, the area to the north of the quire between the piers of the Norman tower, and again first encounter Byrhtnoth and company. In both processual circumstances, when entering through the nave or through the north-west transept, the first memorial monument encountered by the pilgrim beyond any in the nave was that of Byrhtnoth. This demarcation is made more significant when entering from the

\footnotetext{
$76 \quad$ King, "Ely Cathedral," p. 218.

77 Nilson, Cathedral Shrines, p. 94.

78 Coatsworth, "Byrhtnoth's Tomb," p. 280.

79 C. Pamela Graves, "Social Space in the English Medieval Parish Church," Economy and Society 18:3 (1989), 297-322.
} 
nave. Processions through space marked a transformation for the pilgrim; movement through portals and spaces signalled not only a change in location but a change in state "between earthly and spiritual realms". ${ }^{80}$ Here, as a pilgrim moved from the more secular and profane space of the nave into the more sacred space at the crossing, the Byrhtnoth monument marked this transition into a differing place.

If both entrances, nave and transept, are used at this stage in the 12th century, a simplified spatial analysis shows a nice social idea of the space. Although the space of the north crossing, the most likely location of Byrhtnoth and friends, is not the highest prestige space-that still belongs to the shrine to the east of the high altar-it is the most trafficked space (See Fig. 26.3). It is even a location on the pilgrim trail that was later marked in iconographic ways as the start within this holy space: the 14th-century capitals of the interior of the octagon depict the salient points of the life of Æthelthryth, ${ }^{81}$ with the first depicting her unwilling marriage at this northwest point (See Fig. 26.4). The point at the start of this pictorial cycle of the capitals is also the same point that pilgrims would enter the crossing on their way to the Æthelthryth shrine; this point in the northwest of the north transept was the beginning of the path in the sacred space.

Beyond that there remains further difficulty in how historians have read the monument. This monument has been read in both medieval and modern times from left to right, i.e. from Wulfstan to Byrhtnoth. We can see this as early as the compiler of Liber Eliensis, in his excuses for writing these worthy men out of order. However, the reading of this monument relies on two very basic facts that have not been taken into account. In order to 'read' the monument this way, from left to right, one must be approaching it straight on, from dead centre. We have already seen that this would not have been the case. Secondly, one must be able to read to 'read' this monument from left to right. One must spatially understand western text to be read from left to right to 'read' a monument as text, to understand and express a monument in these terms. This probably was not the case with the average pilgrim who would have encountered the monument, with an already demonstrable preference of lay pilgrims

8o Simon Coleman and John Elsner, Pilgrimage Past and Present: Sacred Travel and Sacred Space in the World Religions (Cambridge, MA, 1995), p. 6; quote from Karl Kinsella, "Doorways as Liminal Structures in Anglo-Saxon Text and Image," Leeds Studies in English, New Ser. 48 (2017), 43-55, at p. 44.

81 Virginia Blanton-Whetsell, "Imagines Ætheldredæ': Mapping Hagiographic Representations of Abbatial Power and Religious Patronage," Studies in Iconography 23 (2002), $55^{-107}$. 

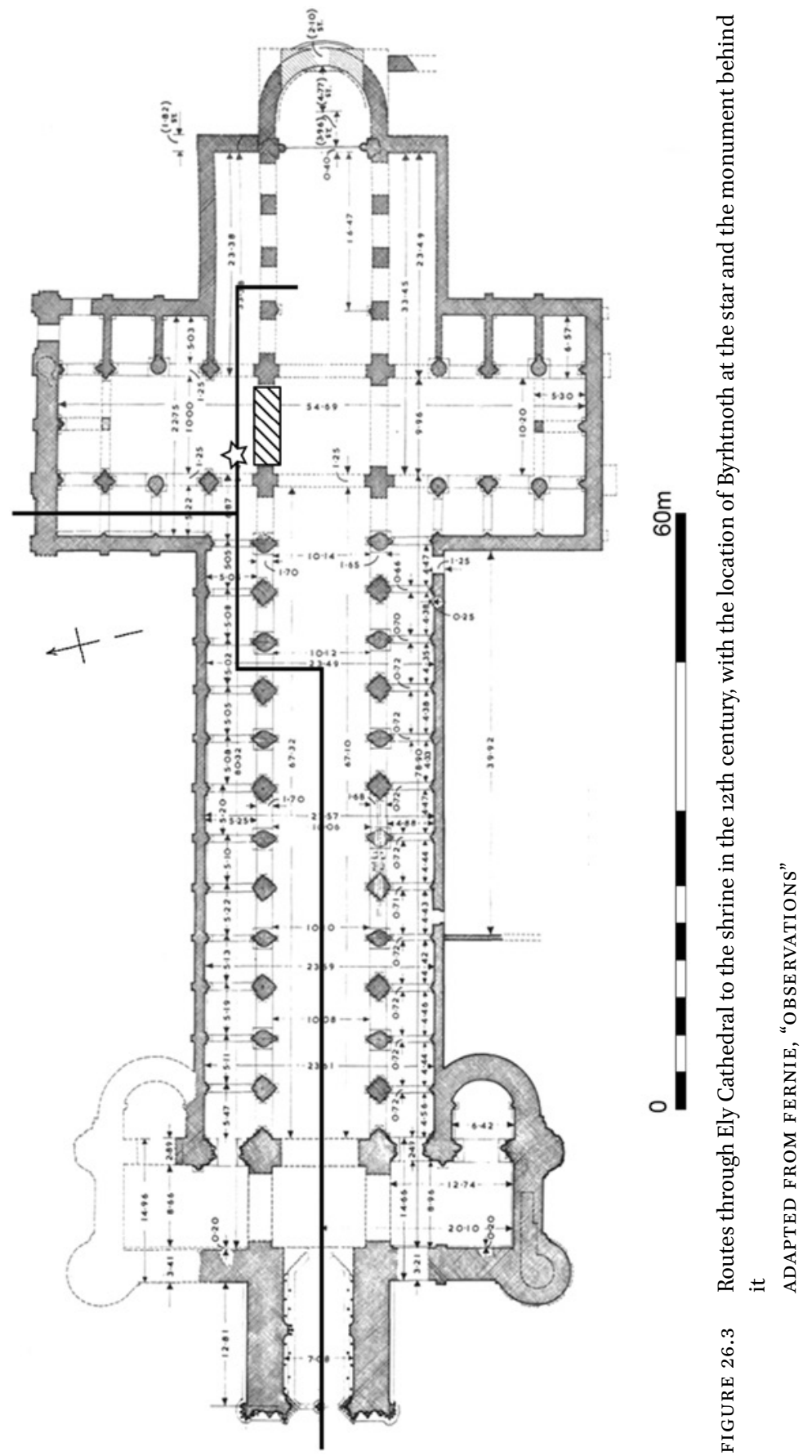


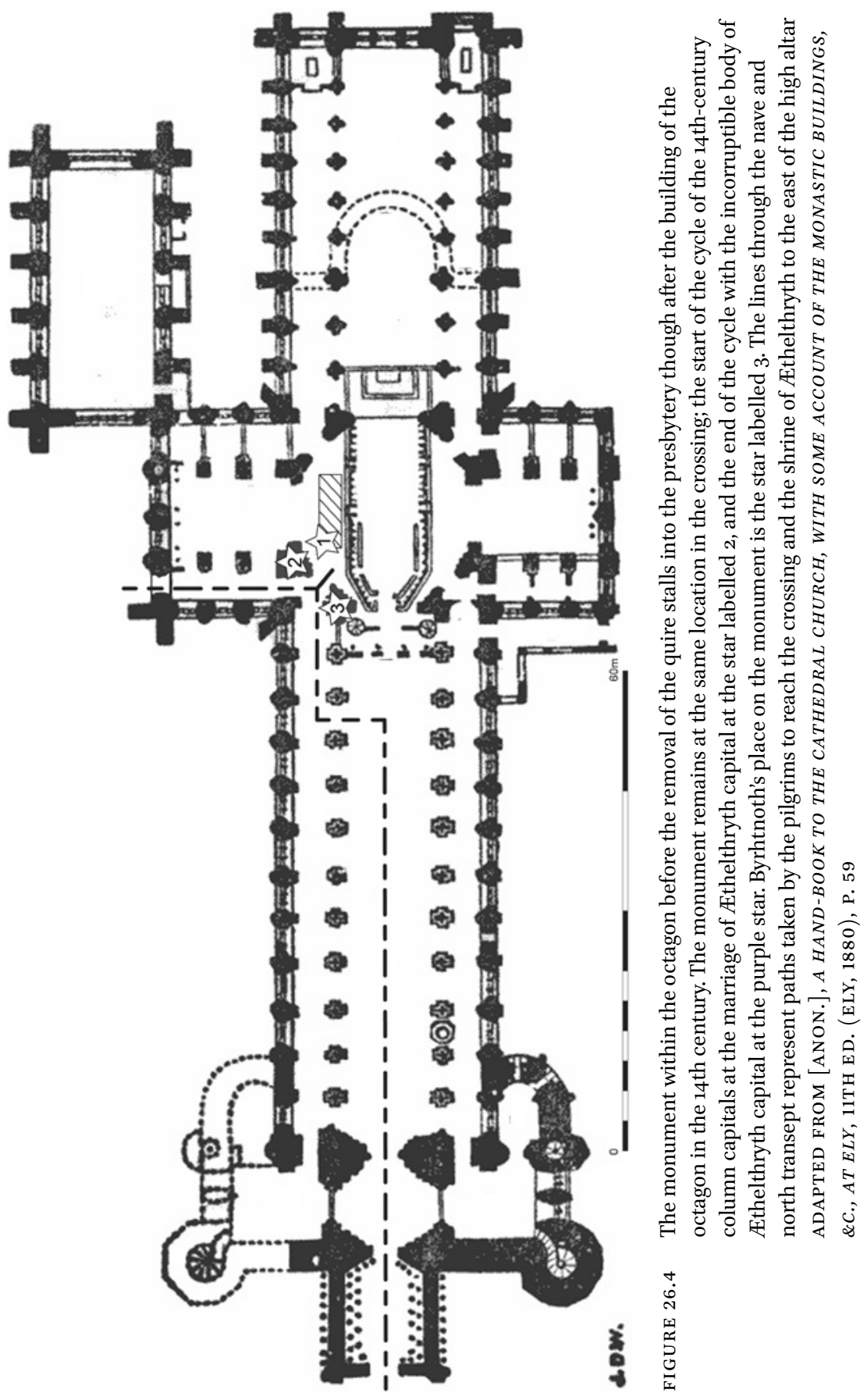




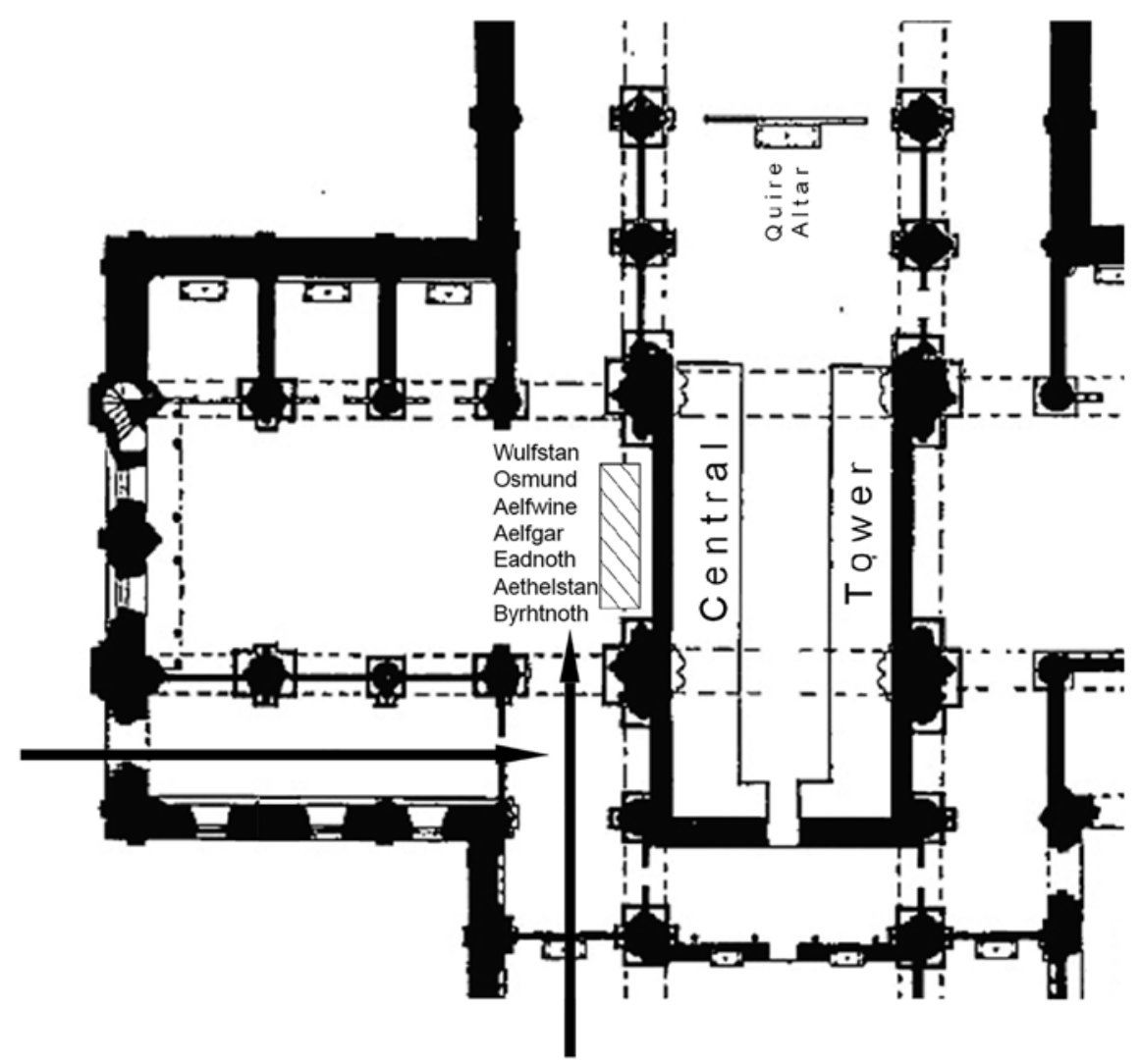

FIGURE 26.5 Routes from nave and transept, intersecting with the Byrhtnoth monument at the location of Byrhtnoth

ADAPTED FROM ATKINSON, "CATHEDRAL"

at the site by the time of the 14 th century. ${ }^{82}$ And as a matter of fact, for pilgrims coming from either the nave or the northwest transept entrance, the first worthy they would have seen was Byrhtnoth himself (see Fig. 26.5).

Spatially speaking, what then is happening here with this monument at this place? As noted above, by the mid- to late 12th century, western Europe was in the grips of what Jo Ann McNamara has called the Herrenfrage, the crisis of masculinity. As religious leadership struggled to maintain control in the face of double monasteries, powerful abbesses, questions over clerical marriage and other aspects both of female religious authority and the perceived denigration of masculine religious authority, sacred and secular men were encouraged to "establish their own dominance at any cost." ${ }^{83}$ A part of this gender

82 Blanton, "Building a Presbytery," p. 543.
$83 \quad$ McNamara, "Herrenfrage," p. 19. 
restructuring has been read into the disassociation and disavowment of dualsex monastic establishments. Ely, of course, had already de-established itself as a double monastery. At its refoundation in 970 in the throes of King Edgar's Benedictine reforms, ${ }^{84}$ it had become a male-only monastery. But they still had older female founders who happened to be saints and bring them a certain amount of income from pilgrims. When Ely translated their seven worthy men into the new cathedral, they were flaunting their masculine re-foundation in an attempt to memorialize new, masculine founders. All seven of these men were benefactors to Ely; some, like Byrhtnoth, great ones. One man in particular, Wulfstan, was in the process of potentially becoming a local saint; remember that Liber Eliensis records miracles that were taking place at his grave, and carefully notes shrouds, pins, and so forth that could be trotted out at a gravesite as contact relics ( $L E$ II. 87$).{ }^{85}$ This new potential relic spot represented by the seven worthies gave Ely a claim on a more appropriate (for the mid-12th century) male foundation. ${ }^{86}$ The location of this monument, erected where pilgrims would encounter it before reaching the female Anglo-Saxon saints, would give Ely's founding men first strike at the shaping of memory culture represented by the cathedral monuments on the pilgrim's trail. The monument intervened with the creation of the memory of Ely's past, in a way that Ely carefully chose and crafted with these seven men. Their importance was noted in their placement, and the male configuration of the seven worthies interrupting the path to female saints show Ely pressing their 1oth-century masculine refoundation at the middle of the 12th century.

\section{Conclusions}

The afterlife of Byrhtnoth makes for interesting readings, as much now as it did then. But in our focus to read Byrhtnoth as a singular man, a certain persona, much has been lost in terms of the context of his persona as a part of a painstakingly actualized group identity in the place of Ely Cathedral. It is here that group identities representing not only holiness and patronage but also political resistance and gender restructuring were brought en force to define very real social and political movements in the 12th century. The seven worthy men here were not presented as foreign but familiar, never mind that none would have been within living memory, all existed under a different rule of a different

\footnotetext{
84 "Houses of Benedictine Monks," pp. 199-210.

85 Lionarons, Homiletic Writings of Archbishop Wulfstan, p. 10.

86 Their female founders were also being rewritten in masculinized terms at this time; see Blanton-Whetsell, "Tota integra," 256-59.
} 
ruling class, and one in particular was far less identifiably English in ethnicity or career than the others. The theoretical 'past as a foreign country' as well as the foreigners within their past were made into something useably, identifiably English, and English for Ely's purposes. This monument, in the 12th centuries and beyond, was viewed by pilgrims from England and across Western Europe, and it was here that Ely was attempting to write themselves and their identity to those visitors.

The monument was certainly something wholly appropriate to a monastic memorial, demonstrating that masculinity and piousness-and generosity, of course-can go hand-in-hand. But beyond this, in the wider world of the 12th century, more can be said. It was here within this monument that Ely presented a subtext of resistance, perhaps in recognition of the region's long-standing tradition of harbouring and fermenting rebellion. In the mid-12th century, when the Isle itself was frequently under threat from both factions of the civil war, this subtext of resistance and survival was certainly an acute feeling. And in an even more personal level, the monument could represent the monks' own resistance to Nigel. There was a certain amount of plausible deniability to this, to be sure, but in a monastery often at odds with its bishop, this subtext cannot be denied.

But even beyond this we can place this monument in the larger framework of 12th-century Europe. Amongst gender restructuring in the 12th century, we can see Ely physically representing their two foundations in ways best suited for the time. Their female saints and founders were no less important, and certainly their status and placement within the monastic memory, history and mythology would not be taken away-to say nothing of the income earned from the shrines of these Anglo-Saxon women. But Ely suddenly found it appropriate to fete their refoundation and their male benefactors. The context of this memorial in its location in Ely Cathedral represents an attempt at providing Ely a set of masculine venerables in contrast to their popular female saints. Through this we can read a physical representation of Herrenfrage, a reassertion of a hierarchical masculinity at the end of the 12 th century. ${ }^{87}$ Byrhtnoth and these holy men became a tool of an ecclesiastic hierarchy reasserting holy and masculine values in alignment with their attempt to provide Ely with further saints to fill their spiritual and financial coffers.

In short, this monument was no mere ossuary, no simple piece of stone to reflect upon. The group identities represented in this monument reflected a very real political and social present to the monks and the pilgrims at Ely Cathedral in the 12th century, one that was cast onto a wider European stage by

87 McNamara, "Herrenfrage." 
virtue of the pilgrims to the site. In this the cycle would repeat itself: Ely was taking in wider Western European ideas about gender and monasticism, while at the same time perpetuating and repeating these ideas back to their visitors, asserting their identity as pious, rebellious, and masculine. 